\title{
The Use of Cytochrome $b$ Gene as a Specific Marker of the Rat Meat (Rattus norvegicus) on Meat and Meat Products
}

\author{
H. Nuraini*, A. Primasari, E. Andreas, \& C. Sumantri \\ Department of Animal Production and Technology, Faculty of Animal Science, Bogor Agricultural University \\ Jln. Agatis, Kampus IPB Darmaga, Bogor 16680, Indonesia \\ (Received 28-03-2011; accepted 26-11-2011)
}

\begin{abstract}
ABSTRAK
Pemalsuan daging dan produk olahannya dengan daging tikus merupakan masalah yang harus diatasi untuk menjamin keamanan pangan. Salah satu cara yang sering digunakan untuk mendeteksi pemalsuan adalah dengan menggunakan gen sitokrom $b$ sebagai penanda. Tujuan penelitian ini adalah untuk membuat primer spesifik berasal dari sekuen sitokrom b pada tikus (Rattus norvegicus) sebagai penanda DNA untuk mendeteksi adanya kontaminasi daging tikus pada daging segar dan produk olahannya. Bakso dibuat dari daging sapi dengan penambahan daging tikus $1 \%-25 \%$, dan bakso yang diperoleh dari pasar tradisional. Ekstraksi DNA dilakukan dari tujuh spesies (kambing, ayam, sapi, domba, babi, kuda, dan tikus) dengan menggunakan metode fenol-kloroform. Amplifikasi gen sitokrom $b$ dari tujuh spesies hewan dengan panjang fragmen yang berbeda menunjukkan kekhususan gen sitokrom $b$ diantara spesies. Hasil amplifikasi panjang fragmen untuk ternak kambing, ayam, sapi, domba, babi, kuda, dan tikus adalah 157, 227, 274, 331, 398, 439 dan 603 pb. Tingkat keberhasilan tertinggi dalam mendeteksi adanya daging tikus dalam campuran bakso daging sapi dengan daging tikus pada konsentrasi $15 \%$ adalah $100 \%$. Fragmen spesifik gen sitokrom b dari $R$. norvegicus tidak memiliki kesamaan dengan gen sitokrom b dari enam spesies lainnya, sehingga dapat digunakan sebagai penanda molekuler untuk mendeteksi adanya kontaminasi daging tikus pada daging segar maupun produk olahannya.
\end{abstract}

Kata kunci: gen sitokrom b, Rattus norvegicus, produk daging olahan

\section{ABSTRACT}

Falsification of the origin of livestock meat and its processed with rat meat is a problem that must be overcome to ensure food safety. One way that is often used to detect forgeries by using $c y$ tochrome $\mathbf{b}$ gene as a marker. The purpose of this study was to create a specific primer derived from cytochrome $\mathrm{b}$ sequences in rat (Rattus norvegicus) as the DNA marker to detect any contamination of rat meat on fresh livestock meat and its processed meat products. Meatballs were made from beef meat with the addition of rat $1 \%-25 \%$, and the meatballs were obtained from traditional markets. DNA extraction was conducted from seven species (goat, chicken, cattle, sheep, pig, horse, and rat) by using phenol-chloroform. The highest success rate in detecting the presence of rat meat in a mixture of beef meatballs at concentration of $15 \%$ was $100 \%$. The specific fragment of cytochrome b gene in $R$. norvegicus has no similarity with the cytochrome b gene from six other species, so it can be used as molecular markers to detect the presence of rat meat contamination in the processed of meat products. Amplified fragment length for goats, chickens, cattle, sheep, pigs, horses, and rats 157, 227, $274,331,398,439$ and $603 \mathrm{bp}$ respectively. The amplification of cytochrome b gene in seven species of animals with different fragment length indicated the specificity of cytochrome $\mathbf{b}$ gene sequences among species.

Key words: cytochrome b (cyt b) gene, Rattus norvegicus, meat products

${ }^{*}$ Corresponding author:

E-mail: hennynuraini@ymail.com 


\section{INTRODUCTION}

The advancement of food technology has grown rapidly including the provision of raw materials, processing, serving, and packaging. Along with these developments, the food safety of animal origin is to be the attention of consumers. Food safety is food that can satisfy consumer needs and free from contaminants/ hazards such as physical, chemical and biological aspects of halal for Moslem consumers. The meat mixing with animals forbidden to consume, such as donkey, wild animals, dogs, and rats, to cut the price has worried Moslem community.

Genetic traceability is based on the identification of both animals and their products through the DNA analysis. The use of DNA techniques provides different levels of identification: (i) individual traceability to ensure food safety; and (ii) traceability of individuals to their source breed or species to detect possible labelling adulteration (Dalvit et al., 2007). The process of multiplication of DNA sequences by polymerase chain reaction technique (PCR) is another alternative in the determination of the existence of fraud or other species contamination in a product (Zhang et al., 2007; Ghovvati et al., 2009). This method uses a universal DNA marker or a specific marker which is only found in a species of animal. Nuraini (2004) has been reported that specific sequences Porcine Repetitive Element 1 (PRE-1) can be used to detect the pigs (Sus scrofa) and their relatives. Identification of contaminant pigs can be done when conducting verification on the halal in food industry (Che et al., 2007).

$C y t b$ gene is a gene that is often used to compare multiple phylogenetic species in the same genus or family, the diversity of the cyt $b$ gene has been used to detect the source of milk derived from cattle (Bos), sheep (Ovis) and goats (Capra) and buffalo (Bubalus) (Lanzilao et al., 2005). Pfeiffer et al. (2004) has identified the diversity of the $c y t b$ gene in the species of cattle (Bos taurus), sheep (Ovis Aries), goats (Capra hircus), roe buck (Capreolus capreolus) and red deer (Cervus elaphus) (Wolf et al., 1999). Species of rat (Rattus norvegicus) have long sequences of cyt $b$ gene of 1143 bp (Naidu et al., 2010), while in Bos taurus 1140 bp in length (Geng and Chang, 2008). Research report on the contamination of livestock meat and processed meat products with rat meat in Indonesia is less informed; therefore the use of specific markers with high accuracy needs to be done to protect consumers from meat falsification.

The aims of this study were: (1) to create a specific primer derived from genus of Rattus $c y t b$ sequences, and (2) to determine the level of similarity (homology) of rat $c y t b$ gene sequences with other animals commonly consumed (goat, chicken, cattle, sheep, pig, and horse). The specific primers marker designed expected to be used as a mixture of DNA to detect the presence of rat meat in livestock raw meat and meat products. The benefit from this research was to assist the government in deciding the halal certification of food products from livestock.

\section{MATERIALS AND METHODS}

\author{
Specific Primers
}

Specific primers used for amplification of DNA fragments goat, chicken, cattle, sheep, pig, and horse followed the method of Matsunaga et al. (1999). Forward primer used for the seven animals were the same, namely 5'-GACCTCCCAGCTCCATCAAACATCTCATCTTGAT GAAA-3 '. While a reverse primer specific for rat was designed using the software primer designing tool (http://www.ncbi.nlm.nih.gov/tools/primerb last/index. shtml), and the sequences are presented in Table 1. The primer reverse of $c y t b$ gene sequence was homologized by BLASTN-NCBI.

\section{DNA Extraction}

Blood samples taken from goat, chicken, cow, sheep, pig, horse, and rat, and meatballs from meat beef mixed with rat meat were used for DNA extraction. There were two kinds of meatballs used in this experiment, first was made in the laboratory by mixing ground beef with rat meat with a composition ratio of $1 \%, 5 \%$, $10 \%, 15 \%$, and $25 \%$, and the second was purchase directly from traditional markets in Bogor. Rat used as a compound derived from the species $R$. norvegicus albino strain. The process of DNA isolation used phenol-chloroform method (Sambrook \& Russell, 2001). Sampling from traditional market was conducted to determine the presence of rat meat in meatballs. The quantitative measurement of DNA purity and its concentration was done by using a spectrophotometer to ensure successful DNA extraction, while the DNA test results in a qualitative extraction is done by electrophoresis on $1 \%$ agarose gel run at $100 \mathrm{~V}$ for $40 \mathrm{~min}$.

\section{Amplification of Specific DNA Fragments from Several Animals by Using Multiplex PCR}

Amplification of specific DNA fragments was made by PCR (polymerase chain reaction) method. Reaction components, as much as $25 \mathrm{~mL}$, consisted of 35 pmol forward primer, reverse primer each 5 pmol, $200 \mu \mathrm{M}$ dNTP mixture, $1 \mathrm{mM} \mathrm{MgCl}_{2}$, taq polymerase 0.5 units and buffer, and $124.95 \mathrm{~mL} \mathrm{H}_{2} \mathrm{O}$. The process of amplification was run on a GeneAmp ® PCR System 9700 (Applied

Table 1. Specific primer sequence for several animals

\begin{tabular}{llc}
\hline \multicolumn{1}{c}{ Species } & \multicolumn{1}{c}{ Reverse $\left(5^{\prime} \rightarrow 3^{\prime}\right)$} & $\begin{array}{c}\text { PCR } \\
\text { products }\end{array}$ \\
\hline Goat* $^{*}$ & CTC GAC AAA TGT GAG TTA CAG AGG GA & $157 \mathrm{bp}$ \\
Chicken* $^{*}$ & AAG ATA CAG ATG AAG AAG AAT GAG GCG & $227 \mathrm{bp}$ \\
Cattle* $^{*}$ & CTA GAA AAG TGT AAG ACC CGT AAT ATA AG & $274 \mathrm{bp}$ \\
Sheep $^{*}$ & CTA TGA ATG CTG TGG CTA TTG TCG CA & $331 \mathrm{bp}$ \\
Pig $^{*}$ & GCT GAT AGT AGA TTT GTG ATG ACC GTA & $398 \mathrm{bp}$ \\
Horse* $^{*}$ & CTC AGA TTC ACT CGA CGA GGG TAG TA & $439 \mathrm{bp}$ \\
Rat* $^{*}$ & GAA TGG GAT TTT GTC TGC GTT GGA GTT T & $603 \mathrm{bp}$ \\
\hline Note: $^{*}$ Matsunaga et al. (1999), ${ }^{* *}$ primer designed &
\end{tabular}


Biosystems ${ }^{\mathrm{TM}}$ ) with the denaturation conditions began at $94{ }^{\circ} \mathrm{C}$ for $5 \mathrm{~min}, 35$ denaturation cycles at $94{ }^{\circ} \mathrm{C}$ for 45 sec, annealing at $60^{\circ} \mathrm{C}$ for $45 \mathrm{sec}$ and elongation of new DNA at $72{ }^{\circ} \mathrm{C}$ for $1 \mathrm{~min}$, and final elongation at $72{ }^{\circ} \mathrm{C}$ for 5 min.

\section{The Interpretation Results Visualization and Amplification}

Visualization of amplification performed on agarose gel 2\% (v/w) was stained with EtBr (ethidium bromide) above transiluminator UV irradiation. Specific DNA fragment goat, chicken, cattle, sheep, pig, horse, and rat were analyzed by standard DNA size marker (100 bp).

\section{RESULTS AND DISCUSSION}

\section{The Degree of Similarity Cyt $b$ Gene Sequence}

The homology percentage of reverse specific primers between rat with sheep, horse, pig, goat, chicken, and cattle, were $64.29 \%, 64.29 \%, 67.86 \% \%, 71.43 \%, 75.00 \%$, and $78.57 \%$ (Table 2); while the homology percentage of specific primers in the same species was $100 \%$ the same, except in sheep that was only $96.2 \%$. The reverse primer traces have a high homology percentage in one particular animal species and low in other species, so it can be said that reverse primer is specific to a particular animal species. The homology percentage among different species was in the range of $80 \%-100 \%$, so it could be used as a general primer.

\section{Total DNA Quality}

The DNA purity was good enough, because no negative values obtained. According Tataurov et al. (2008), fluorescent dye in solution can yield a negative value. The concentration of DNA extraction varied from 50 to $1410 \mu \mathrm{g} / \mathrm{ml}$ was caused by different sources of extracted samples, that were blood and meat products (meatballs). The existence of different ingredients in a product will affect the concentration of DNA produced. According to Nuraini (2004), the use of spices and other ingredients in the product meatballs, such as starch and sodium tripolyphosphate, will cause the DNA extracted compound still mixed with contaminants, such as polysaccharides, oligopeptide, and other organic materials. The process of extraction methods determined the quality and quantity of DNA produced, sometimes it was needed some modification process depends on the origin of the material extracted. Generally, the raw tissue was easier to extract than the tissue that had been cooked or mixed with other ingredients. The DNA concentration used in the process of copying DNA through PCR was $50 \mathrm{ug} / \mathrm{ml}$. DNA samples with concentrations higher than $50 \mathrm{ug} / \mathrm{ml}$ could be processed by adding destilated water.

\section{Amplification of Specific Fragments of $C y t b$ Gene on Several Species of Livestock}

Cyt $b$ gene successfully amplified using the primers follow Matsunaga et al. (1999) for six species of livestock, there were goat, chicken, cattle, sheep, pig, and horse; while rat samples using primer of software tools based on $c y t b$ gene sequences in $R$. norvegicus. The success of the $c y t b$ gene amplification on the seven animals with different length of fragments showed the specificity of cyt $b$ gene sequences between species. The amplification fragment length of goat, chicken, cattle, sheep, pig, and horse according to Matsunaga et al. (1999) were 157, 227, 274, 331, 398 and 439 bp, respectively. In this study, a rat sequence had 603 bp fragment length (Figure 1). Furthermore Wolf et al. (1999) and Alves et al. (2009) mentioned that cyt $b$ can be used as a marker to determine the variation interspecies and subspecies on several types of livestock/animals. Cyt $b$ gene PCRRFLP method could also be used in identifying pig (Sus scrofa domesticus), rabbit (Oryctolagus cunniculus) and goose (Anser anser) with successively truncated at 115 bp, not cut off at 130 and $229 \mathrm{bp}$ (Minarovic et al., 2010). Duplication of DNA molecules on the target sequences from several species simultaneously (using the same forward primer) PCR is a variation of a technique called multiplex PCR (Jain et al., 2007). Visualization of specific DNA fragments of the cyt $b$ gene amplification results in this study was presented in Figure 2.

\section{Amplification of Specific Fragments of DNA Cyt $b$ in the DNA Mixture}

Primer specificity tests with 6 levels of beef and pork or beef with rat mixture $(1 \%, 5 \%, 10 \%, 15 \%, 20 \%$, and $25 \%$ ) had been done, and the obtained results for each species were tested. The result showed that

Table 2. The homology percentage of specific reverse primers (38 bp) in several animals

\begin{tabular}{lccccccc}
\hline Spesific primer & Goat & Chicken & Cattle & Sheep & Pig & Horse & Rat \\
\hline Forward (38 bp) & 100.00 & 86.8 & 92.1 & 86.8 & 80.00 & 100.00 & 92.00 \\
Goat (26 bp) & $\mathbf{9 6 . 1 5}$ & 42.31 & 73.08 & 23.08 & 76.92 & 73.08 & 73.08 \\
Chicken (27 bp) & 74.07 & $\mathbf{1 0 0 . 0 0}$ & 37.04 & 25.93 & 51.85 & 33.33 & 77.78 \\
Cattle (29 bp) & 75.86 & 44.83 & $\mathbf{1 0 0 . 0 0}$ & 72.41 & 37.93 & 79.31 & 75.86 \\
Sheep (26 bp) & 92.31 & 53.85 & 73.08 & $\mathbf{1 0 0 . 0 0}$ & 50.00 & 65.38 & 76.92 \\
Pig (27 bp) & 37.04 & 55.56 & 77.78 & 33.33 & $\mathbf{1 0 0 . 0 0}$ & 81.48 & 85.19 \\
Horse (26 bp) & 80.77 & 65.38 & 73.08 & 76.92 & 76.92 & $\mathbf{1 0 0 . 0 0}$ & 88.46 \\
Rat (28 bp) & 71.43 & 75.00 & 78.57 & 64.29 & 67.86 & 64.29 & $\mathbf{1 0 0 . 0 0}$ \\
\hline
\end{tabular}


the specific primer of cattle, pig, and rat successfully amplified cyt $b$ gene sequences (Figure 3). The success rate of specific primers amplified cyt $b$ gene sequences of cattle and rat varied from $8.3 \%$ to $91.7 \%$ (Table 3 ). The existence of rat meat on the beef meatball greater than $15 \%$ had been clearly detected, but at $1 \%$ level it did not detected properly. This was probably because of poor mixing process.

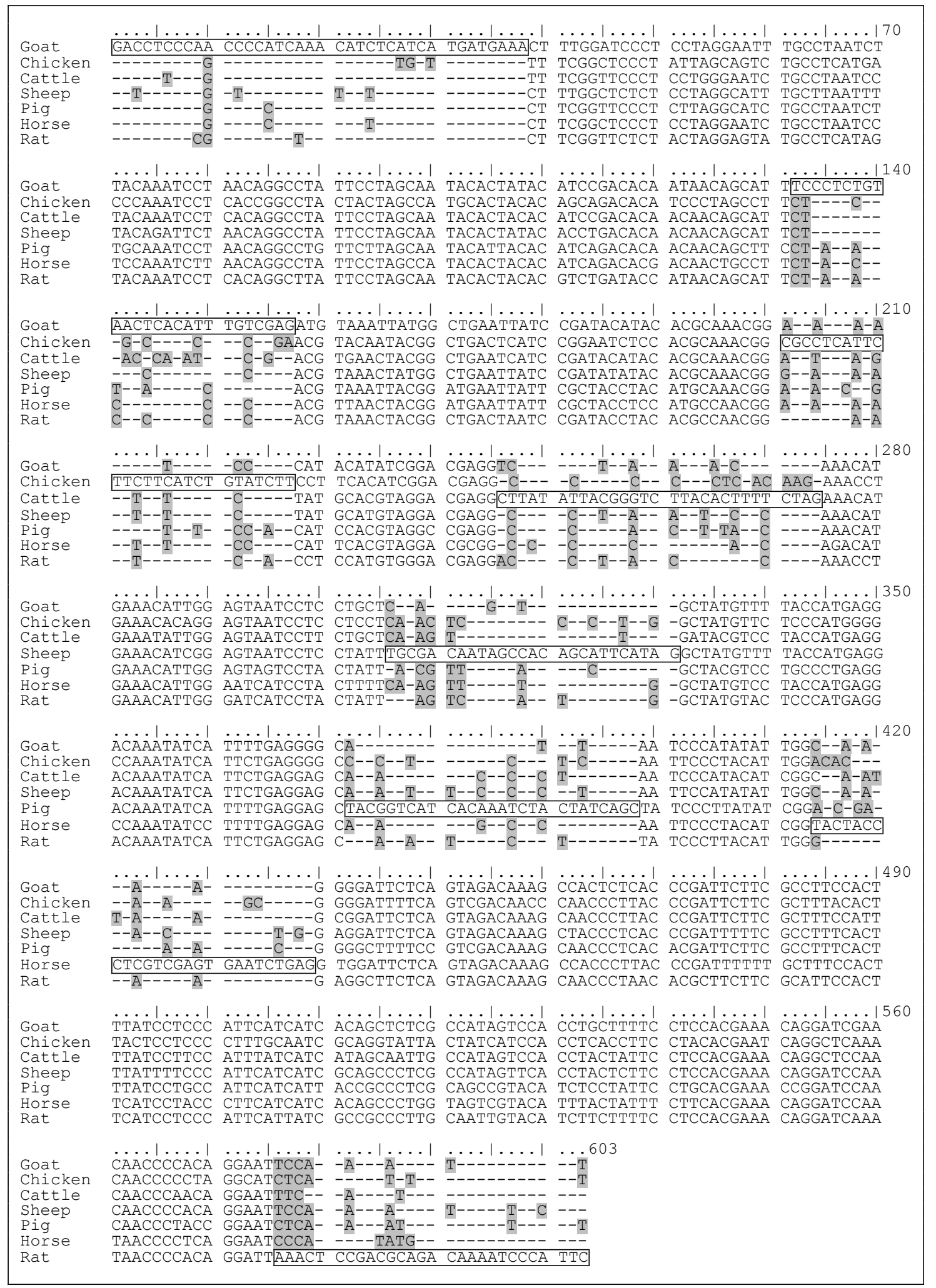

Figure 1. Primers sequence and target region on cytochrome $b$ gene. Open boxes indicate forward and species-specific reverse primer. Dots and dash indicate different and identical nucleotides to the primer sequences. 


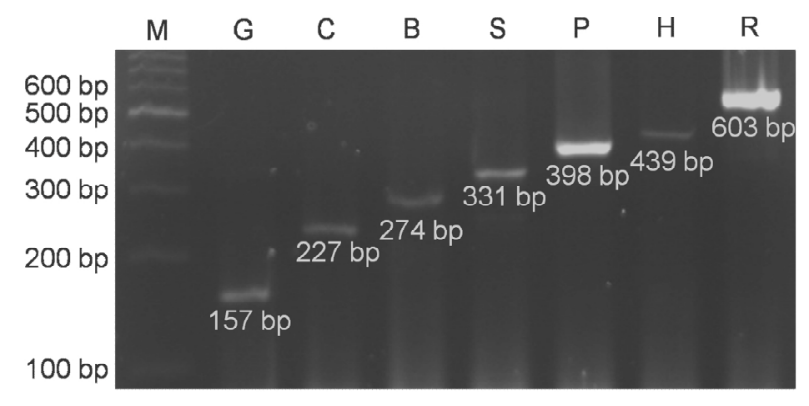

Figure 2. DNA fragments specific for each type of animal. M: marker 100 bp, G: Goat, C: chicken, B: cattle, S: sheep, P: pig, H: horse, and R: rat.

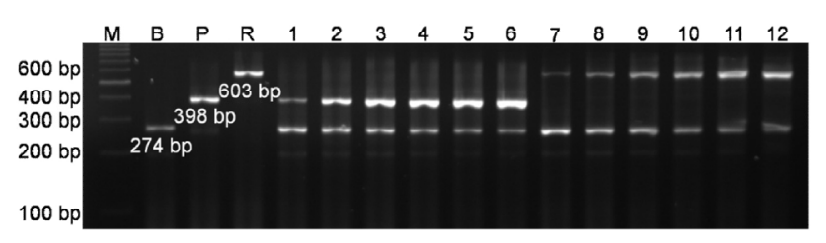

Figure 3. Amplification of specific fragments of DNA mixtures. M: marker $100 \mathrm{bp}$, B: positive control cattle, P: positive control pork, R: positive control rat, 1-6: DNA mixture of pork : beef $(1 \%, 5 \%, 10 \%, 15 \%, 20 \%$, and $25 \%)$, and 7 12: DNA mixture of rat : beef $(1 \%, 5 \%, 10 \%, 15 \%, 20 \%$, and $25 \%)$.

Table 3. The success rate of $C y t b$ gene amplification on raw meat and beef meatballs mixed with rat (1\%-25\%) $(\%)$

\begin{tabular}{lcccc}
\hline \multirow{2}{*}{ Sample } & \multicolumn{2}{c}{ Raw } & \multicolumn{2}{c}{ Meat ball } \\
\cline { 2 - 5 } & Beef & Rat & Beef & Rat \\
\hline Beef & 100 & - & 100 & - \\
Rat & - & 100 & - & 100 \\
Beef + Rat & 100 & 100 & 100 & 100 \\
Meatballs 1\% & 100 & 100 & 100 & 8.3 \\
Meatballs 5\% & 100 & 100 & 100 & 91.7 \\
Meatballs 10\% & 100 & 100 & 100 & 66.7 \\
Meatballs 15\% & 100 & 100 & 100 & 100 \\
Meatballs 20\% & 100 & 100 & 100 & 100 \\
Meatballs 25\% & 100 & 100 & 100 & 100 \\
Negative control & 0 & 0 & 0 & 0 \\
(water) & & & &
\end{tabular}

\section{Amplification of DNA Fragments Specific $C y t b$ Gene at Meatball Laboratory}

Primary testing was also conducted on the meatballs mixed with rat meat consisted of six levels of contamination $(1 \%, 5 \%, 10 \%, 15 \%, 20 \%$, and $25 \%)$. The results showed the success rate of beef and rat specific primers for the $c y t b$ gene amplified sequence on speciesspecific regions (Figure 4).

The success of specific primers amplified beef samples containing DNA was $100 \%$. This acquisition showed

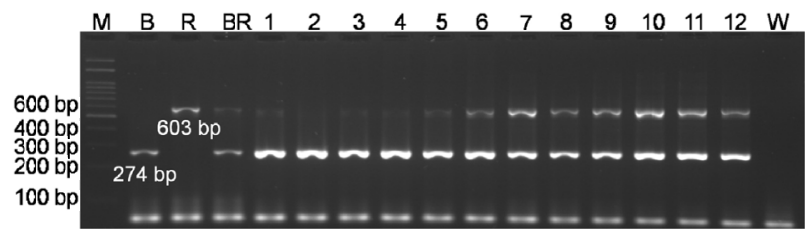

Figure 4. Amplification of specific DNA fragments cyt $\mathrm{b}$ in meatballs samples. M: marker $100 \mathrm{bp}, \mathrm{B}$ : control bovine DNA, R: DNA control rat, BR: DNA control mixture of beef: rat (1:1). 1-2: rat meatballs $1 \%, 3-4$ : $5 \%$ rat meatballs, 5-6: $10 \%$ rat meatballs, $7-8: 15 \%$ rat meatballs , 9-10: rat meatballs $20 \%$, 11-12: rat meatball $25 \%$, and $\mathrm{W}$ : negative control (water).

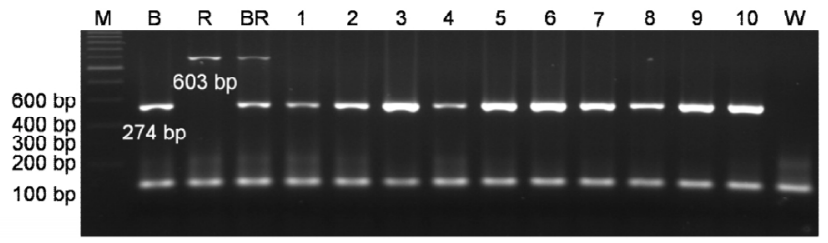

Figure 5. Amplification of specific DNA fragments of cyt b in meatball samples. M: marker $100 \mathrm{bp}$, B: control bovine DNA, R: DNA control rat, BR: DNA control mixture of beef : rat (1:1). 1-10: meatball samples from traditional markets in Bogor, and W: negative control (water).

that the band appeared in all samples containing bovine DNA, while the average success rate of rat-specific primer was $8.3 \%-100 \%$. Meatballs samples containing $1 \%$ rat meat appeared in the first sample on third amplification, while three other samples at the same level did not. This was probably because of the less homogeneous process of grinding meat. Meatballs containing 15\% rat meat above showed successful amplification up to $100 \%$ (Table 3). Several researchers previously reported that the PCR technique can be used to identify a mixture of meat mixture on the level of $0.5 \%$ and $1 \%$ (Zhang et al., 2007; Ilhak \& Arslan, 2010). Thus the use of PCR technique could be one identification method of livestock/ animals.

\section{Amplification of Specific Fragments of DNA Cyt b Gene on Meatballs in Traditional Markets}

The result indicated that no sample meatballs from traditional market mixed by rat meat. The visualization of DNA by $2 \%$ agarose gel electrophoresis only showed bovine specific bands, while the specific bands for rat was negative (Figure 5). The DNA amplification result of traditional market meatballs is presented in Table 3.

\section{CONCLUSION}

The highest success rate in detecting the presence of rat meat in a mixture of beef meatballs at concentration of $15 \%$ was $100 \%$. The specific fragment of cytochrome b gene in $R$. norvegicus has no similarity with the cytochrome $\mathrm{b}$ gene from six other species, so it can be used as molecular markers to detect the presence of rat meat 
contamination in the processed of meat products. The amplification of cytochrome $b$ gene in seven animals species with different fragment length indicated the specificity of cytochrome b gene sequences among species.

\section{ACKNOWLEDGMENT}

The author would like to thank the Ministry of National Education Republic of Indonesia, which has funded some of these research activities through Fundamental Grant Program (Contract No. 34/13.24.4/ SPK/PD/2010 dated March 5, 2010). Thanks also submitted to the Head of the Livestock Breeding and Genetics, Department of Animal Production and Technology, Faculty of Animal Science Bogor Agricultural University that has been allowed to use the laboratory and the undergraduate and graduate students which has helped in making the study sample.

\section{REFERENCES}

Aberle, E. D., J. C. Forrest, D. E. Gerald, E. W. Mills \& H. B. Hedrick. 2001. Priciples of Meat Science. Fourth Edition. Kendall/Hunt Publishing Company. IOWA USA.

Alves E., A. I. Ferna' ndez-, A. Ferna' ndez-Rodrí'guez, D. $\mathrm{Pe}^{\prime}$ rez-Montarelo, R. Benitez, C. O' vilo, C. Rodrı'guez \& L. Silio. 2009. Identification of mitochondrial markers for genetic traceability of European wild boars and Iberian and Duroc pigs. Animal 3: 1216-1223. DOI: 10.1017/ S1751731109004819

Bellis, C., K. J. Ashton, L. Freney, B. Blair \& L. R. Griffiths. 2003. A molecular genetic approach for forensic animal species identification. Forensic Sci. Int. 134: 99-108. DOI:10.1016/ S0379-0738(03)00128-2

Bielikova, M., D. Pangallo, \& J. Turna. 2010. Polymerase chain reaction - restriction fragment lenght polymorphism (PCR - RFLP) as a molecular discrimination tool for raw and heat-treated game and domestic animal meats. J. Food Nutr. Research. 49: 134-139.

Che, M. Y. B., A. A. Aidah A. R. Raha, \& R. Son. 2007. Identification of pork derivatives in foods products by species-spesific polymerase chain reaction (PCR) for halal verification. Food Ctrl. 18: 885-889. DOI: 10.1016/ j.foodcont.2006.05.004

Dalvit, C., M. De Marchi, \& M. Cassandro. 2007. Genetic traceability of livestock products: A review. Meat Sci. 77: 437449. DOI: $10.1016 /$ j.meatsci.2007.05.027

Geng, R. Q. \& H. Chang. 2010. Genetic diversity and origin of Menggu cattle. http://www.ncbi.nlm.nih.gov/nuccore/193297018. [10 Agustus 2010].

Ghovvati, S., M. R. Nassiri, S. Z. Mirhoseini, A. H. Moussavi, \& A. Javadmanesh. 2009. Fraud identification in industrial meat products by multiplex PCR assay. Food Ctrl 20: 696 - 699. Doi: $10.1016 /$ i.foodcont.2008.09.002

Halal. 2002. Refleksi kasus-kasus halal. Jurnal LP. POM-MUI. No. 41 /VII.

Hamm, R. 1977. Changes of Muscle Proteins During the Heating of Meat. In: T. Hoyem and O. Kvale. Physical, Chemical and Biological Changes in Food Caused by Thermal Processing. Applied Science Publishers Limited. London.

Hsieh, H. M., H. L. Chiang, L. C. Tsai, S. Y. Lai, N. E. Huang, A. Linacre, \& J. C. I. Lee. 2001. Cytochrome b gene for species identification of the conservation animals. Forensic Sci. Int. 122: 7-18. DOI: 10.1016/S0379-0738(01)00403-0

Hsieh, H. M., C-C Tsai, L-C Tsai, H-L Chiang, N-E Huang, R. T-P Shih, A. Linacre \& J. C-I Lee. 2005. Species identification of meat products using the cytochrome $\mathrm{b}$ gene. J. Forensic Sci. 4: 29-36.
Ilhak, O. I. \& A. Arslan. 2007. Identification of meat species by polymerase chain reaction (PCR) technique. Turk. J. Vet. Anim. Sci. 31: 159-163.

Jain, S., M. N. Brahmbhait, D. N. Rank, C. G. Joshi \& J. V. Solank. 2007. Use of cytochrom b gene variability in detecting meat spesies by multiplex PCR assay. Ind J. Anim. Sci. 77: 880-881.

Kesmen, Z., H. Yetim, \& F. Sahin. 2010. Identification of different meat species used in sucuk production by PCR assay. GIDA 35: 81-87.

Lanzilao, I., F. Burgalassi, S. Fancelli, M. Settimelli \& R. Fani. 2005. Polymerase Chain Reaction-Restriction Fragment Length Polymorphism analysis of mitochondrial cytb gene from species of dairy interest. J. AOAC Int. 88: 128-135.

Matsunaga, T., K. Chikuni, R. Tanabe, S. Muroya, K. Shibata, J. Yamamda \& Y. Shinmura. 1999. A quick and simple method for the identification of meat species and meat products by PCR assay. Meat Sci. 51: 143-148. DOI: 10.1016/S03091740(98)00112-0

Minarovic, T., A. Trakovicka, A. Rafayova, \& Z. Lieskovska. 2010. Animal species identification by PCR-RFLP of cytchrome b. Scientific Papers: Anim. Sci. \& Biotech. 43: 296.

Naidu, A., R. R Fitak, A. Munguia-Vega, \& M. Culver. 2010. Novel PCR primers for complete mitochondrial cytochrome $b$ gene sequencing in mammals. Mol. Ecol. Resources. 12: 191-196.

NCBI. 2000. Rattus norvegicus Mitochondrial Gene for Cytochrome b, Partial cds.http://www.ncbi.nlm.ni.gov.

Nuraini, H. 2004. Pengembangan sekuen Porcine Repetitive Element-1 (PRE-1) sebagai penanda molekuler untuk mendeteksi material babi pada produk daging olahan. Disertasi. Sekolah Pascasarjana, IPB. Bogor.

Ockerman, H. W. 1983. Chemistry of Meat Tissue. Dept. of Anim. Sci. The Ohio State Univ. and The Ohio Agricultural Research and Development Center. Ohio. USA.

Parson, W., K. Pegoraro, H. Niederstatter, M. Fofer, \& M. Teilechner. 2000. Species identification by means of the cytochrome b gene. Int J. Legal Medic. 114: 23-28. DOI: 10.1007/ s004140000134

Pfeiffer, I., J. Burger, \& B. Brenig. 2004. Diagnostic polymorphism in the mitochondrial cytochrome $b$ gene allow discrimination between cattle, sheep, goat, roe buck and red deer by PCR-RFLP. BMC Genet. 5:30-34. DOI:10.1186/14712156-5-30

Primasari, A. 2011. Sensitivitas gen sitokrom b (cyt b) sebagai marka spesifik pada genus Rattus dan Mus untuk menjamin keamanan pangan produk asal daging. Tesis. Sekolah Pasasarjana, Institut Pertanian Bogor.

Sambrook, J. \& D. Russell. 2001. Molecular Cloning: A Laboratory Manual, 3rd ed. Cold Spring Harbor Laboratory Press, United State of America.

Spychaj, A., P. Mozdziak, \& E. Pospiech. 2009. Identification of poultry meat from pork and beef on the basis of the titin pevk region using PCR. J. Muscle Foods 20: 341-351. DOI: 10.1111/j.1745-4573.2009.00152.x

Tataurov, A. V., Y. You, \& Owczarzy. 2008. Predicting ultraviolet spectrum of single stranded and double stranded deoxyribonucleic acids. Biophys. Chem. 133: 66-70. DOI: 10.1016/j.bpc.2007.12.004

Undang-undang Republik Indonesia. 1999. Undang-undang Republik Indonesia No.8 tentang Perlindungan Konsumen. Lembaran Negara RI Tahun 1999 Nomor 42.

Wolf, C., J. Rentsch, \& P. Hübner. 1999. PCR-RFLP Analysis of mitochondrial DNA: A reliable method for species identification. J. Agric. Food Chem. 47: 1350-1355. DOI: 10.1021/ jf9808426

Zhang, C. L., M. R. Fowler, N. W. Scott, G. Lawson, \& A. Slater. 2007. A Taqman real-time PCR system for the identification and quantify rication of bovine DNA in meats, milks and cheeses. Food Ctrl. 18: 1149-1158. DOI: 10.1016/ j.foodcont.2006.07.018 